\title{
Trends in fracture development of the upper extremity in Germany-a population-based description of the past 15 years
}

\author{
P. Hemmann ${ }^{*}$, P. Ziegler, C. Konrads, A. Ellmerer, T. Klopfer, A. J. Schreiner and C. Bahrs
}

\begin{abstract}
Background: Recent studies investigating fracture development in Germany are not available especially with regard to demographic change. The primary aim of this study was to report trends in fracture development of the upper extremity in Germany between 2002 and 2017 and to evaluate changes over time.

Methods: Evaluating inpatient data from the German National Hospital Discharge Registry (International Classification of Diseases, ICD-10) between 2002 and 2017. Total count, incidences and percentage changes of the following fracture localizations were analysed: proximal humerus, distal humerus, proximal ulna, proximal radius, ulna diaphysis (including Monteggia lesion) and distal radius. Ten age groups for men and women were formed: $35-44,45-54,55-64,65-74 ; 75-84 ; 85-90$, and $>90$ (years).
\end{abstract}

Results: The total count of proximal humeral fractures increased from 40,839 (2002, men/women 9967/30,872) to 59,545 (2017, men/women 14,484/45,061). Distal humeral fractures increased from 5912 (2002, men/women 1559/ 4353) to 6493 (2017, men/women1840/4653). The total count of forearm fractures increased from 68,636 (2002, men/women $17,186 / 51,450)$ to 89,040 (2017, men/women $20,185 / 68,855)$. Women were affected in $70-75 \%$ of all cases with rising incidences among nearly every age group in female patients.

Conclusion: Total count of nearly every evaluated fracture increased. Also, incidences increased especially in the older female age groups. Fracture development already seems to reflect demographic changes in Germany.

\section{Introduction}

Demographic change and increased life expectancies lead to an overaged population in Germany. According to the German Federal Office of Statistics, more than $50 \%$ of the population will be older than 50 years by the year 2050 [1]. Hence, the amount of geriatric fractures will increase [2], associated with high effort and high costs for the public health care system [3]. In light of this, surgeons will be confronted with higher numbers of (low-energy-associated fractures due to age-related diseases like osteoporosis and accidental falls $[4,5]$. Especially, osteoporosis, with high prevalence in people over 50 years [6], causes typical fractures of the elderly

\footnotetext{
*Correspondence: philhemmann@gmail.com

Department of Traumatology and Reconstructive Surgery, BG Trauma Center Tuebingen, Eberhard Karls University Tuebingen, Schnarrenbergstrasse 95, 72076 Tuebingen, Germany
}

affecting the proximal humerus, distal radius, proximal femur, ankle joint, spine and pelvis [7-10]. Treatment of these fractures and comorbidities respectively represents a challenge for the attending physician.

Although, there are several studies dealing with epidemiology of hip fractures [3, 11, 12], there is no study which describes the development of fractures in Germany, especially fracture development of the upper extremity. A few epidemiological studies of other countries have been published in the last years about fracture development of the proximal and distal humerus $[2,7,13,14]$.

The goal of the present study was to analyse the epidemiological development of fractures between 2002 and 2017 in Germany. Trends in fractures of the upper extremity were evaluated for people $>35$ years of age with focus on the elderly respectively by analysing the national hospital discharge diagnosis register. Moreover,

(c) The Author(s). 2020 Open Access This article is distributed under the terms of the Creative Commons Attribution 4.0 International License (http://creativecommons.org/licenses/by/4.0/), which permits unrestricted use, distribution, and 


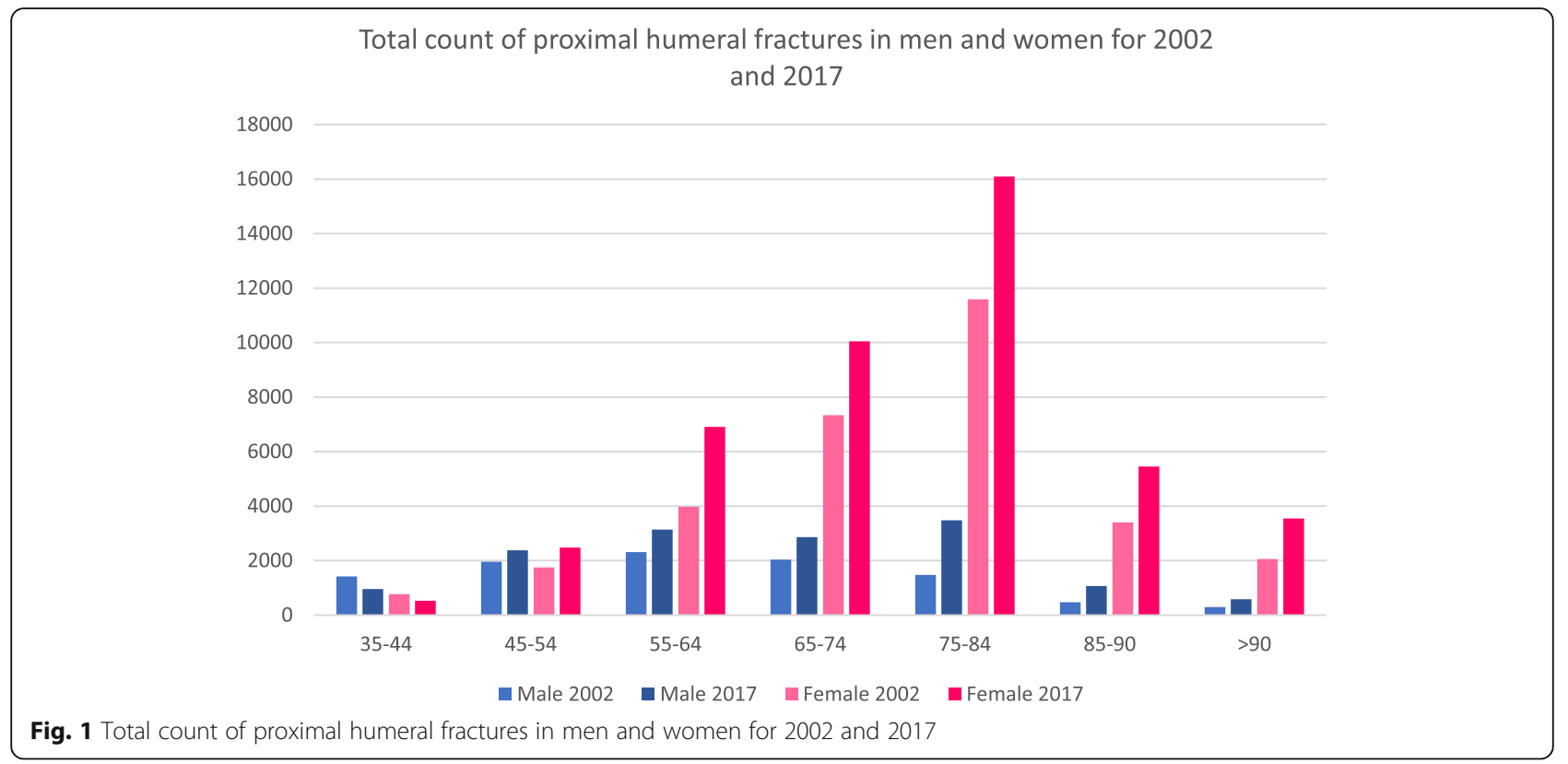

the study presents the shift of prevalences and incidences in different fractures of the upper extremity.

\section{Patients and methods}

The authors analysed nationwide data of the national hospital discharge diagnosis register between 2002 and 2017. This database is maintained by the RKI (Robert Koch Institute) and the German Federal Office of Statistics. Therefore, it includes patient data of more than $99 \%$ of all German hospitals and can provide reliable epidemiological information. Previous studies have already demonstrated the validity of this data base [15].

The International Classification of Diseases (ICD) system was used to identify relevant diagnosis. ICD-10-GM (German modification) was evaluated for the following fractures: proximal humerus/S42.2, distal humerus/ S42.4, proximal ulna/S52.0, proximal radius/S52.1, ulna diaphysis/S52.2 (including Monteggia-Lesions) and distal radius/S52.5. ICD-10-GM codes have been used since

Table 1 A total count, differences between 2017 and 2002 in percent and incidences for 2002 and 2017 for proximal humerus fractures for men and women. Total count and incidences for patients $>90$ years have been added together

\begin{tabular}{|c|c|c|c|c|c|c|}
\hline \multirow{2}{*}{$\begin{array}{l}\text { Proximal } \\
\text { humerus } \\
\text { fracture } \\
\$ 42.2\end{array}$} & \multirow{2}{*}{$\begin{array}{l}\text { Age } \\
\text { (years) }\end{array}$} & \multicolumn{2}{|c|}{ Total count } & \multirow{2}{*}{$\begin{array}{l}\text { Ratio (\%) } \\
\text { 2017:2002 }\end{array}$} & \multicolumn{2}{|c|}{ Incidence ( $n / 100,000 /$ year) } \\
\hline & & 2002 & 2017 & & 2002 & 2017 \\
\hline \multirow[t]{7}{*}{ Male } & $35-44$ & 1416 & 962 & -32 & 19.7 & 19.1 \\
\hline & $45-54$ & 1961 & 2381 & 21 & 34.4 & 36.5 \\
\hline & $55-64$ & 2316 & 3135 & 35 & 46.4 & 53.8 \\
\hline & $65-74$ & 2033 & 2865 & 41 & 53.6 & 72.8 \\
\hline & $75-84$ & 1470 & 3486 & 137 & 92.0 & 113.5 \\
\hline & $85-90$ & 471 & 1072 & 128 & 216.8 & 203.3 \\
\hline & $>90$ & 300 & 583 & 94 & 229.7 & 304.8 \\
\hline \multirow[t]{7}{*}{ Female } & $35-44$ & 770 & 530 & -31 & 11.3 & 10.8 \\
\hline & $45-54$ & 1749 & 2480 & 42 & 31.2 & 38.8 \\
\hline & $55-64$ & 3973 & 6910 & 74 & 77.8 & 116.1 \\
\hline & $65-74$ & 7333 & 10,050 & 37 & 165.8 & 229.1 \\
\hline & $75-84$ & 11,587 & 16,095 & 39 & 365.2 & 397.5 \\
\hline & $85-90$ & 3399 & 5453 & 60 & 518.2 & 563.2 \\
\hline & $>90$ & 2061 & 3543 & 72 & 460.1 & 612.2 \\
\hline
\end{tabular}




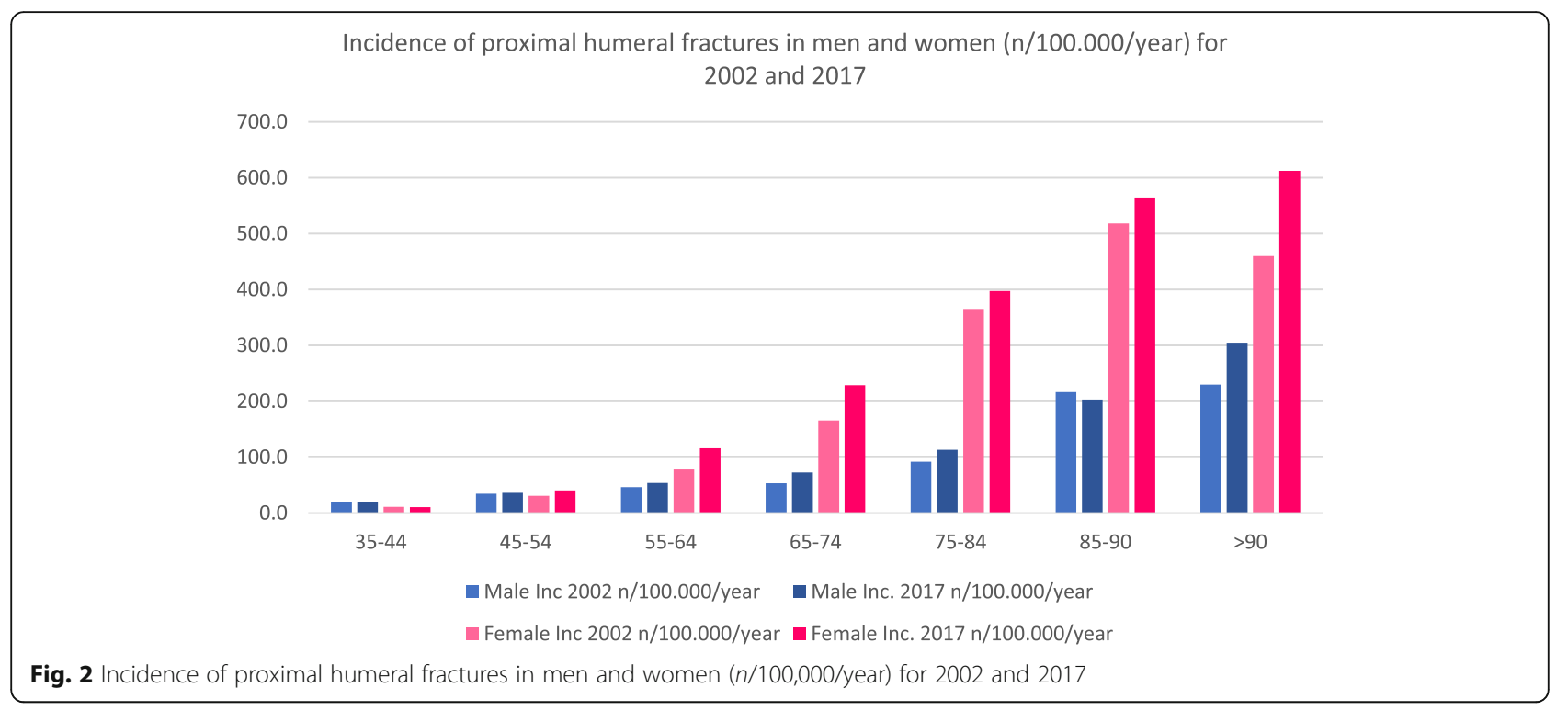

2000. To minimise documentation errors after changing to ICD-10-GM, the authors determined 2002 as starting point for further study analysis [16].

Men and women were split into age groups with a range of 10 years per age group: 35-44, 45-54, 55-64, $65-74,75-84,85-90$, and $>90$. All patients $>90$ years were analysed in one group.

Furthermore, the national hospital discharge diagnosis register provides demographic data about suitable age groups for men and women for the years 2002 and 2017 and the population for both sexes for each year was used to calculate the fracture incidence per each corresponding age group $(n / 100,000 /$ year).

We analysed the total count and incidence of several fractures of the upper extremity from the year 2002 and 2017 and evaluated differences in sex and age groups and percentage changes were evaluated

Statistical analysis was performed with Microsoft $\odot$ Office Excel 365 ProPlus (Microsoft Corporation, Redmond, USA). Descriptive statistical analysis displays prevalences and incidences $(n / 100,000 /$ year) as well as diagrams.

\section{Results}

\section{Proximal humerus}

Forty thousand eight hundred thirty-nine fractures were registered (men/women $9967 / 30,872$ ) in the year 2002. Data showed an increase to 59,545 fractures (men/women 14,484/45,061) in 2017 (46\%). Further evaluation showed that the part of female fractures was $75.6 \%$ and men $24.4 \%$ in 2002 , while nearly the same distribution with $75.7 \%$ women and $24.3 \%$ men occurred in 2017 (Fig. 1). Total counts, incidences and changes between 2017 and 2002 are presented in Table 1. The increase could be stated in all age groups, except the young ones. Especially in the male age group of 75-84 years, data showed a high increase with 137\%. Similar could be stated for males in the age group of 85-90 years. Women aged 75 years and older showed a two to three times higher incidence of proximal humerus fractures than men. Figure 2 shows also that the incidence is rising in both genders.

Table 2 Total count, differences between 2017 and 2002 in percent and incidences for 2002 and 2017 for distal humerus fractures for men and women. Total count and incidences for patients $>90$ years have been added together [16]

\begin{tabular}{|c|c|c|c|c|c|c|}
\hline \multirow{2}{*}{$\begin{array}{l}\text { Distal } \\
\text { humerus } \\
\text { fracture } \\
\text { S42.4 }\end{array}$} & \multirow{2}{*}{$\begin{array}{l}\text { Age } \\
\text { (years) }\end{array}$} & \multicolumn{2}{|c|}{ Total count } & \multirow{2}{*}{$\begin{array}{l}\text { Ratio (\%) } \\
\text { 2017:2002 }\end{array}$} & \multicolumn{2}{|c|}{ Incidence ( $n / 100,000 /$ year) } \\
\hline & & 2002 & 2017 & & 2002 & 2017 \\
\hline \multirow[t]{7}{*}{ Male } & $35-44$ & 321 & 178 & -45 & 4.5 & 3.5 \\
\hline & $45-54$ & 330 & 304 & -8 & 5.8 & 4.7 \\
\hline & $55-64$ & 296 & 414 & 40 & 5.9 & 7.1 \\
\hline & $65-74$ & 273 & 300 & 10 & 7.2 & 7.6 \\
\hline & $75-84$ & 228 & 412 & 81 & 14.3 & 13.4 \\
\hline & $85-90$ & 76 & 163 & 114 & 35.0 & 30.9 \\
\hline & $>90$ & 35 & 69 & 97 & 26.8 & 36.1 \\
\hline \multirow[t]{7}{*}{ Female } & $35-44$ & 251 & 158 & -37 & 3.7 & 3.2 \\
\hline & $45-54$ & 338 & 294 & -13 & 6.0 & 4.6 \\
\hline & $55-64$ & 521 & 631 & 21 & 10.2 & 10.6 \\
\hline & $65-74$ & 1010 & 802 & -21 & 22.8 & 18.3 \\
\hline & $75-84$ & 1412 & 1536 & 9 & 44.5 & 37.9 \\
\hline & $85-90$ & 450 & 724 & 61 & 68.6 & 74.8 \\
\hline & $>90$ & 371 & 508 & 37 & 82.8 & 87.8 \\
\hline
\end{tabular}




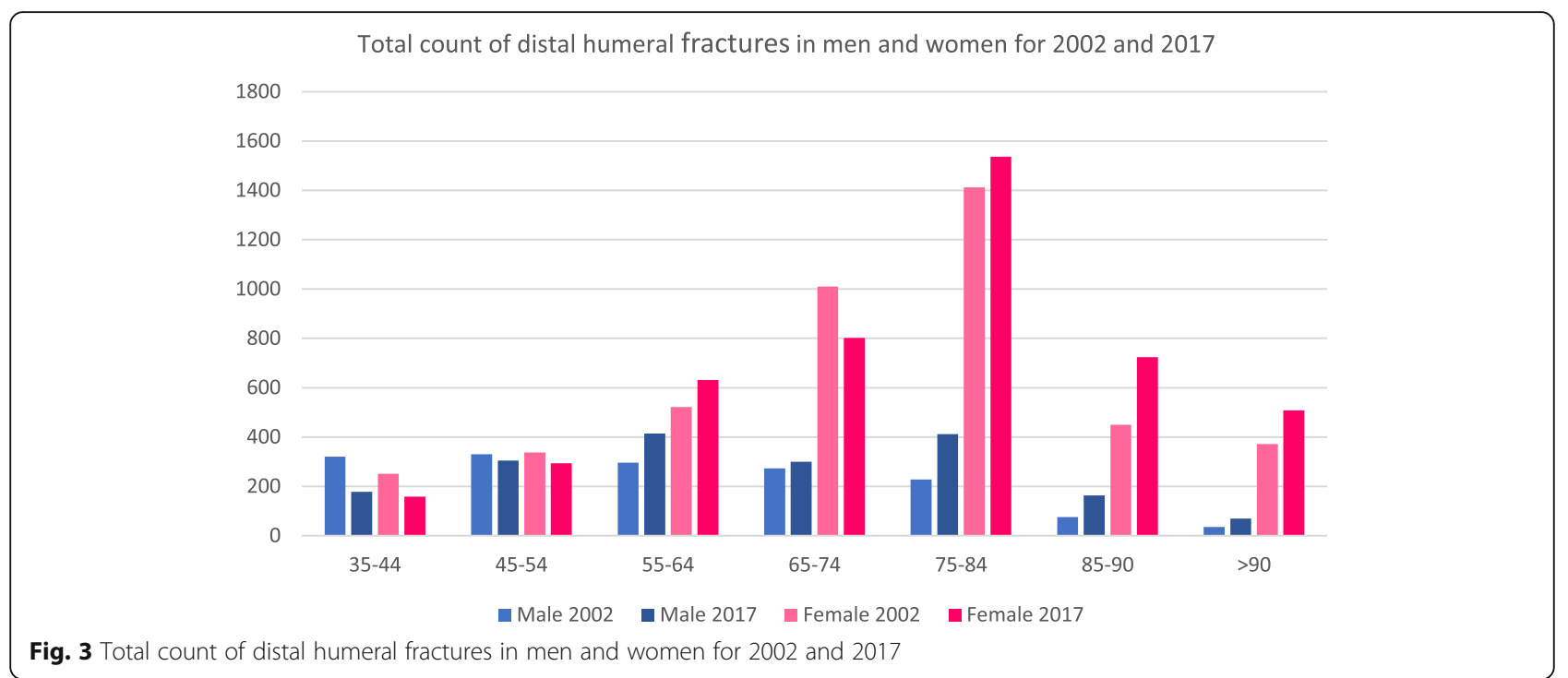

\section{Distal humerus}

Five thousand nine hundred twelve fractures were registered in 2002 located at the distal humerus (men/women 1559/4353). In 2017, a total count of 6493 fractures (men/women 1840/4653) was described with an increase of $9 \%$. The part of female distal humerus fractures in 2002 was $73.6 \%$ (men 26.4\%). In 2017, the percentage of females with distal humeral fractures decreased to $71.7 \%$ (men 28.3\%; Table 2) (Figs. 3 and 4). The youngest age groups showed a decrease of fracture incidences and total counts between 2002 and 2017. The three oldest male age groups showed the strongest ratio increase.

\section{Forearm}

In 2002, a total count of 68,636 fractures were registered (men/women 17,186/women 51,450), whereas 89,040 fractures were registered (men/women 20,185/68,855) in the year 2017 with a total increase of $30 \%$. In $75.0 \%$, female patients suffered from those fractures in 2002 with an increase of 2.3\% until 2017 (men 22.7\%). Typical geriatric fractures like the distal radial fracture showed an increase in both sexes in every age group. Nearly every fracture occurrence of the forearm (proximal, diaphysis, distal) increased in different age groups in both sexes. Table 3 shows the different age groups and the corresponding fracture distribution. Figures 5 and 6 show total counts and incidences summarised for all forearm fractures.

\section{Discussion}

The goal of this study was to analyse trends in fracture development of the upper extremity in people aged $>35$ years in Germany. Main findings were an increase of

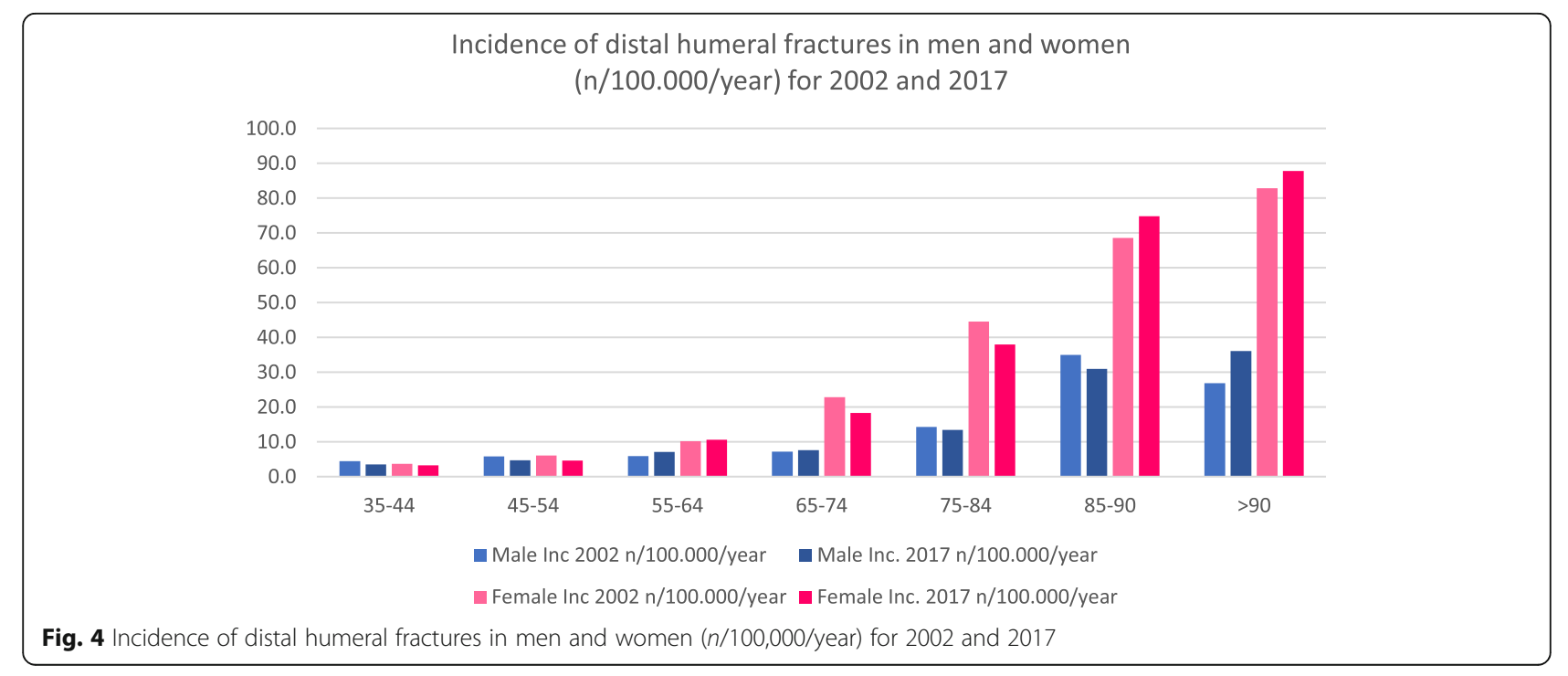


Table 3 Total count, differences between 2017 and 2002 in percent and incidences for 2002 and 2017 for fractures of the forearm for men and women. Absolute numbers and incidences for patients > 90 years have been added together [16]

\begin{tabular}{|c|c|c|c|c|c|c|c|c|}
\hline & \multirow{2}{*}{$\begin{array}{l}\text { Age } \\
\text { (years) }\end{array}$} & \multirow[t]{2}{*}{ Fracture of the } & \multirow{2}{*}{$\begin{array}{l}\text { ICD- } \\
10- \\
\text { Code }\end{array}$} & \multicolumn{2}{|c|}{ Total count } & \multirow{2}{*}{$\begin{array}{l}\text { Ratio (\%) } \\
\text { 2017:2002 }\end{array}$} & \multicolumn{2}{|c|}{ Incidence $(n / 100,000 /$ year) } \\
\hline & & & & 2002 & 2017 & & 2002 & 2017 \\
\hline \multirow[t]{28}{*}{ Male } & \multirow[t]{4}{*}{$35-44$} & Proximal ulna & S52.0 & 776 & 392 & -49 & 10.8 & 7.8 \\
\hline & & Proximal radius & S52.1 & 920 & 729 & -21 & 12.8 & 14.5 \\
\hline & & Ulna diaphysis & S52.2 & 323 & 190 & -41 & 4.5 & 3.8 \\
\hline & & Distal radius & S52.5 & 3005 & 2159 & -28 & 41.8 & 43.0 \\
\hline & \multirow[t]{4}{*}{$45-54$} & Proximal ulna & S52.0 & 679 & 726 & 7 & 11.9 & 11.1 \\
\hline & & Proximal radius & S52.1 & 591 & 874 & 48 & 10.4 & 13.4 \\
\hline & & Ulna diaphysis & S52.2 & 268 & 286 & 7 & 4.7 & 4.4 \\
\hline & & Distal radius & S52.5 & 2839 & 3617 & 27 & 49.9 & 55.5 \\
\hline & \multirow[t]{4}{*}{$55-64$} & Proximal ulna & S52.0 & 628 & 759 & 21 & 12.6 & 13.0 \\
\hline & & Proximal radius & S52.1 & 305 & 535 & 75 & 6.1 & 9.2 \\
\hline & & Ulna diaphysis & S52.2 & 217 & 272 & 25 & 4.3 & 4.7 \\
\hline & & Distal radius & S52.5 & 2780 & 3343 & 20 & 55.7 & 57.4 \\
\hline & \multirow[t]{4}{*}{$65-74$} & Proximal ulna & S52.0 & 431 & 494 & 15 & 11.4 & 12.5 \\
\hline & & Proximal radius & S52.1 & 101 & 205 & 103 & 2.7 & 5.2 \\
\hline & & Ulna diaphysis & S52.2 & 132 & 126 & -5 & 3.5 & 3.2 \\
\hline & & Distal radius & S52.5 & 1845 & 2260 & 22 & 48.6 & 57.4 \\
\hline & \multirow[t]{4}{*}{$75-84$} & Proximal ulna & S52.0 & 250 & 477 & 91 & 15.7 & 15.5 \\
\hline & & Proximal radius & S52.1 & 26 & 107 & 312 & 1.6 & 3.5 \\
\hline & & Ulna diaphysis & S52.2 & 35 & 107 & 206 & 2.2 & 3.5 \\
\hline & & Distal radius & S52.5 & 714 & 1798 & 152 & 44.7 & 58.5 \\
\hline & \multirow[t]{4}{*}{$85-90$} & Proximal ulna & S52.0 & 62 & 136 & 119 & 28.5 & 25.8 \\
\hline & & Proximal radius & S52.1 & 5 & 15 & 200 & 2.3 & 2.8 \\
\hline & & Ulna diaphysis & S52.2 & 8 & 13 & 63 & 3.7 & 2.5 \\
\hline & & Distal radius & S52.5 & 132 & 366 & 177 & 60.7 & 69.4 \\
\hline & \multirow[t]{4}{*}{$>90$} & Proximal ulna & S52.0 & 41 & 65 & 59 & 31.4 & 34.0 \\
\hline & & Proximal radius & S52.1 & 8 & 5 & -38 & 6.1 & 2.6 \\
\hline & & Ulna diaphysis & S52.2 & 3 & 6 & 100 & 2.3 & 3.1 \\
\hline & & Distal radius & S52.5 & 62 & 123 & 98 & 47.5 & 64.3 \\
\hline \multirow[t]{14}{*}{ Female } & \multirow[t]{4}{*}{$35-44$} & Proximal ulna & S52.0 & 446 & 236 & -47 & 6.5 & 4.8 \\
\hline & & Proximal radius & S52.1 & 612 & 492 & -20 & 9.0 & 10.0 \\
\hline & & Ulna diaphysis & S52.2 & 163 & 86 & -47 & 2.4 & 1.7 \\
\hline & & Distal radius & S52.5 & 2459 & 1983 & -19 & 36.0 & 40.2 \\
\hline & \multirow[t]{4}{*}{$45-54$} & Proximal ulna & S52.0 & 514 & 611 & 19 & 9.2 & 9.6 \\
\hline & & Proximal radius & S52.1 & 710 & 1007 & 42 & 12.7 & 15.7 \\
\hline & & Ulna diaphysis & S52.2 & 167 & 186 & 11 & 3.0 & 2.9 \\
\hline & & Distal radius & S52.5 & 4037 & 5491 & 36 & 72.0 & 85.9 \\
\hline & \multirow[t]{4}{*}{$55-64$} & Proximal ulna & S52.0 & 979 & 1076 & 10 & 19.2 & 18.1 \\
\hline & & Proximal radius & S52.1 & 855 & 1372 & 60 & 16.7 & 23.0 \\
\hline & & Ulna diaphysis & S52.2 & 216 & 303 & 40 & 4.2 & 5.1 \\
\hline & & Distal radius & S52.5 & 8561 & 13,195 & 54 & 167.6 & 221.7 \\
\hline & \multirow[t]{2}{*}{$65-74$} & Proximal ulna & S52.0 & 1302 & 1273 & -2 & 29.4 & 29.0 \\
\hline & & Proximal radius & S52.1 & 542 & 838 & 55 & 12.3 & 19.1 \\
\hline
\end{tabular}


Table 3 Total count, differences between 2017 and 2002 in percent and incidences for 2002 and 2017 for fractures of the forearm for men and women. Absolute numbers and incidences for patients > 90 years have been added together [16] (Continued)

\begin{tabular}{|c|c|c|c|c|c|c|c|}
\hline \multirow{2}{*}{$\begin{array}{l}\text { Age } \\
\text { (years) }\end{array}$} & \multirow[t]{2}{*}{ Fracture of the } & \multirow{2}{*}{$\begin{array}{l}\text { ICD- } \\
10- \\
\text { Code }\end{array}$} & \multicolumn{2}{|c|}{ Total count } & \multirow{2}{*}{$\begin{array}{l}\text { Ratio (\%) } \\
\text { 2017:2002 }\end{array}$} & \multicolumn{2}{|c|}{ Incidence $(n / 100,000 /$ year) } \\
\hline & & & 2002 & 2017 & & 2002 & 2017 \\
\hline & Ulna diaphysis & S52.2 & 247 & 287 & 16 & 5.6 & 6.5 \\
\hline & Distal radius & S52.5 & 11,823 & 13,656 & 16 & 267.2 & 311.3 \\
\hline \multirow[t]{4}{*}{$75-84$} & Proximal ulna & S52.0 & 1704 & 1927 & 13 & 53.7 & 47.6 \\
\hline & Proximal radius & S52.1 & 270 & 532 & 97 & 8.5 & 13.1 \\
\hline & Ulna diaphysis & S52.2 & 211 & 312 & 48 & 6.7 & 7.7 \\
\hline & Distal radius & S52.5 & 10,977 & 16,223 & 48 & 346.0 & 400.6 \\
\hline \multirow[t]{4}{*}{$85-90$} & Proximal ulna & S52.0 & 481 & 717 & 49 & 73.3 & 74.1 \\
\hline & Proximal radius & S52.1 & 59 & 75 & 27 & 9.0 & 7.7 \\
\hline & Ulna diaphysis & S52.2 & 57 & 81 & 42 & 8.7 & 8.4 \\
\hline & Distal radius & S52.5 & 2471 & 4318 & 75 & 376.8 & 446.0 \\
\hline \multirow[t]{4}{*}{$>90$} & Proximal ulna & S52.0 & 296 & 471 & 59 & 66.1 & 81.4 \\
\hline & Proximal radius & S52.1 & 39 & 39 & 0 & 8.7 & 6.7 \\
\hline & Ulna diaphysis & S52.2 & 39 & 56 & 44 & 8.7 & 9.7 \\
\hline & Distal radius & S52.5 & 1213 & 2012 & 66 & 270.8 & 347.6 \\
\hline
\end{tabular}

total counts and incidences for proximal and distal humeral fractures especially in older age groups in both sexes. Forearm fractures also showed an increase for both sexes aged over 45 years and the majority of patients suffering from fractures of the upper extremity were female.

There is a lack of epidemiological data for fractures of the upper extremity in the Federal Republic of Germany. There are register studies that investigated fractures of the upper extremity in Sweden and Finland [7, 13, 14]. Sumrein et al. showed, e.g. that mostly females suffer from a proximal humeral fractures with an incidence of $73 \%$ in Sweden [14] and Jo et al. reported about 78\% female patients of their overall cohort in South Korea [17]. This study shows similar results with $75 \%$ females affected by proximal humeral fractures and a gender distribution of men:women of 3:1. Singer et al. and Hagino et al. reported that the incidence of proximal humerus fractures begins to increase after 50 years of age with a female dominance $[18,19]$. We could demonstrate similar results with an increasing total count and incidence for women aged 45 years and older. The rising number

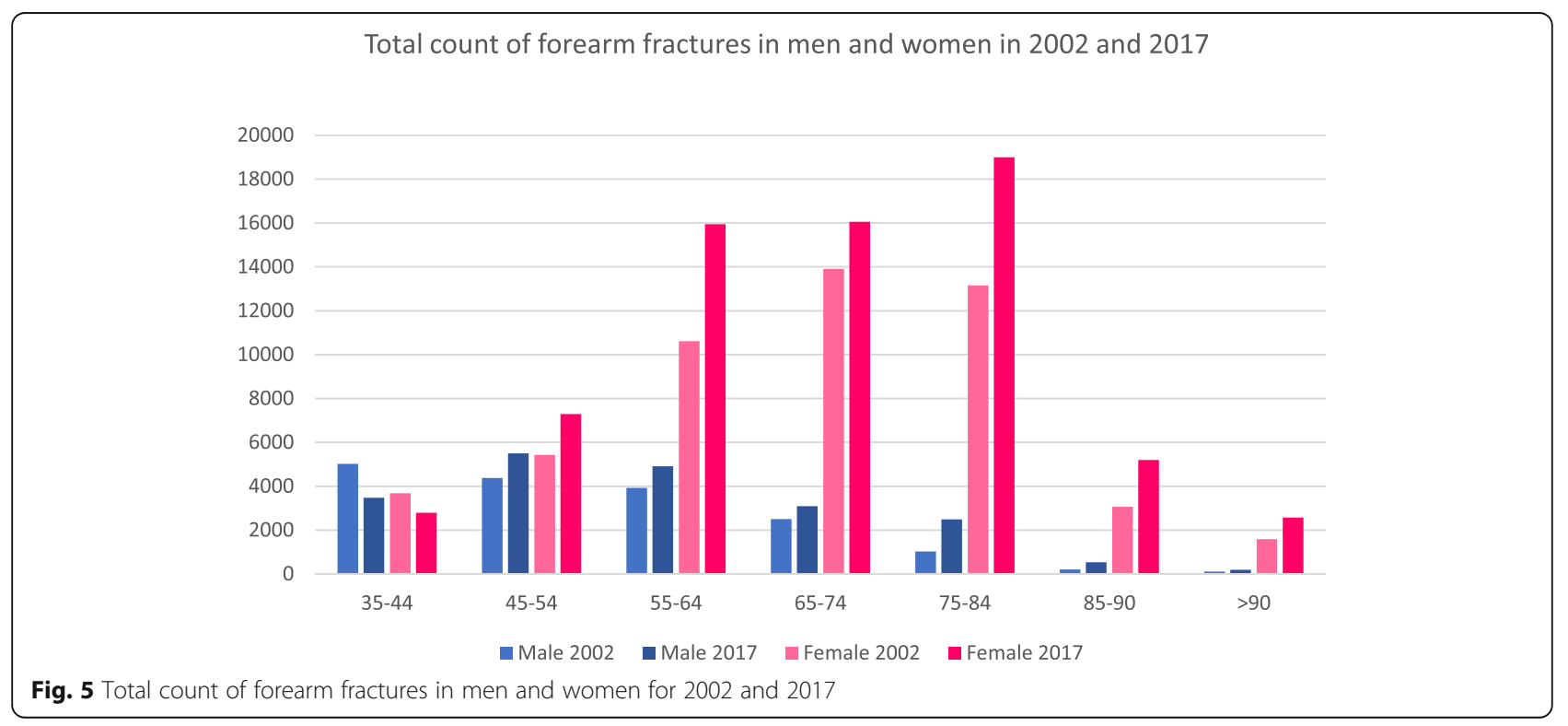


Incidence of forearm fractures in men and women ( $\mathrm{n} / 100.000 /$ year) in 2002 and 2017

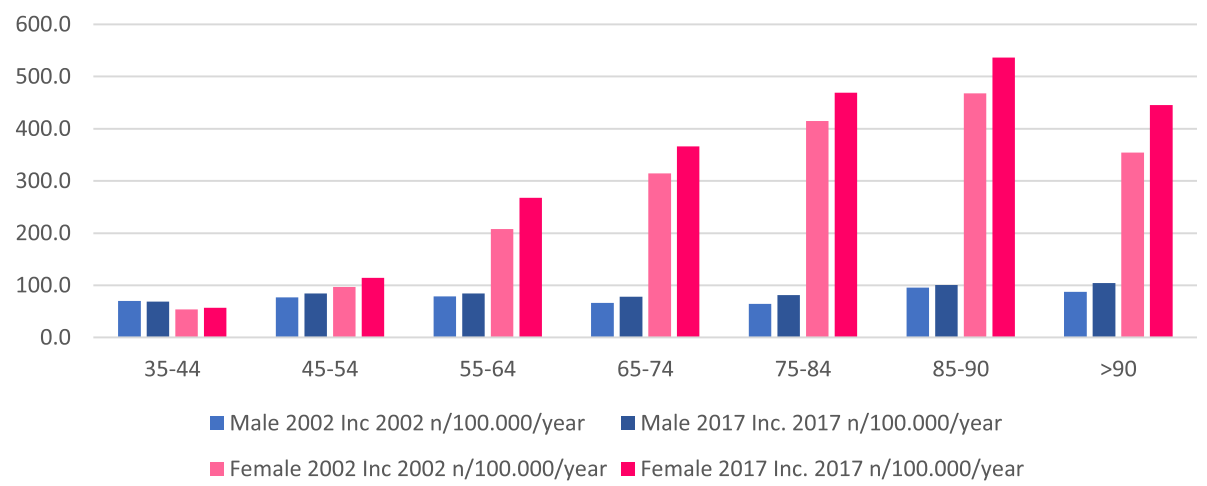

Fig. 6 Incidence of forearm fractures in men and women (n/100,000/year) for 2002 and 2017

of fractures associated with higher age is in accordance with the literature as proximal humeral fractures are also related to fragility fractures $[2,7,20]$.

Similar results were seen for distal humeral fractures. Most noticeable is the change from 81 to $114 \%$ in men aged $>75$ years. However, women still show a higher incidence in every age group $>55$ years. Five percent of all osteoporotic low-energy fractures in people aged 60 years or older are distal humeral fractures [13, 21]. The incidence of fractures of adult women increases every decade after the age of 20 [22] and the incidences for distal humeral fractures in German female patients also show an increasing incidence in every decade (see Fig. $4)$. Bergdahl et al. reported about an increase of incidence after the age of 50 years for men and women which can be related to influencing of age-related risk factors like osteoporosis and a high risk of falls [23]. Distal humeral fractures are usually not regarded as fragility fractures [2]. The strongest change of percentage from 2002 to 2017 (especially in the male group) and an increasing incidence associated with higher age of women suggest that this kind of fracture should also be regarded as a fragility fracture. Court-Brown et al. assumed that distal humeral fractures are osteoporosis related [20]; that is why we think that the high incidence of this fracture type in women associated with the high incidence of osteoporosis in older women in general may strongly support this assumption.

Forearm fractures show a higher incidence for nearly all female age groups compared to men. Until now, fragility fractures of the forearm were mainly focused on the distal radius [7, 24]. Almost every fracture of the forearm increased in incidence in both sexes $>65$ years of age. Especially, the absolute numbers and incidence for women $>55$ years showed a strong increase. Court-
Brown et al. also registered an increasing incidence of ulna diaphyseal fractures in females [2]. An explanation could be a higher life expectation associated with better health and a higher activity level in everyday life. This is confirmed on the one hand by the increased total count of fractures as well as the increased incidence (see Table 3). Nevertheless, a more specific view for fractures of the forearm seems to be necessary. Therefore, these fractures should be reclassified [2] particularly under the aspect of trauma mechanism and age.

Our results showed that demographic change [1] is also reflected by fracture development. Total counts and incidences of typical fragility fractures increased as well as the total spectrum of upper extremity fractures. It seems that there are several reasons why women suffer more often than men from the investigated fractures. Firstly, the amount of old people grows (related to higher life expectancy) and especially the number of older women [25]. Secondly, elderly people are more active than in the past [26]. Thirdly, women suffer from osteoporosis up to 5 times more often than men [27] and osteoporosis manifests earlier in women. As a consequence, fractures occur at a much earlier stage of life and predominantly in women. Women live longer with restrictions due to longer life expectancy and risk of recurring falls [28, 29].

However, men showed an increasing number of fractures, too. They also have a better life expectancy and reach higher ages. Furthermore, it should be considered that men also suffer from osteoporosis. The German osteoporosis guideline group recommends basic diagnostics generally for women and men starting at the age of 70 years due to the increased risk of fractures [30].

The present study has got several limitations. The national hospital discharge diagnosis register only captures 
inpatients. The number of outpatients is not registered which probably increases the absolute numbers of fractures and incidences as well. Additionally, the register does not give any information about fracture classifications and therefore the fracture severity. Mistakes in fracture coding could also be possible. Furthermore, there is no difference between surgically and conservatively treated patients. Another limitation is the lack of recording of osteoporosis diagnoses in relation to the fractures.

This study highlights several problems. Trauma surgeons will have to deal with a growing number of upper extremity fractures in multimorbid as well as active geriatric patients in a probably more complex and demanding general setting as proximal humerus fractures, e.g. show a more complex fracture morphology in elderly patients than in the past years [31]. The authors could demonstrate that this also applies to nearly all fractures of the upper extremity. Health care will therefore be confronted with an increasing fracture rate of geriatric patients and consecutively with a growing financial burden. Another reason is that many patients have multiple side diagnoses. Therefore, interdisciplinary cooperation between trauma surgeons, geriatricians, nursing staff and rehabilitation specialists is necessary [32]. The high number of women suffering from fractures suggests that a sufficient osteoporosis diagnosis and therapy is still not performed although there are several prevention programmes. The German health care planning and hospital-based therapeutic strategies should focus more on the geriatric patient population.

\section{Conclusion}

This is the first study that describes the fracture development of the upper extremity in Germany for patients aged $>35$ years in the years 2002 and 2017. The general assumption so far that fragility fractures only describe proximal humeral and distal radial fractures does not seem to be accurate [2]. Especially, fractures of the distal humerus and forearm occur more often in elderly patients than 15 years ago.

\section{Abbreviations \\ ICD: International Classification of Diseases; ICD-10-GM: International Classification of Diseases 10th version German Modification; RKI: Robert Koch Institute}

\section{Acknowledgements}

Not applicable

\section{Authors' contribution}

$\mathrm{PH}$ developed the study design, performed the statistical data analysis and interpretation and was a major contributor in writing the manuscript. PZ revised the manuscript. CB supervised the project and revised the manuscript. KC and KT revised the manuscript. EA drafted and wrote the manuscript. AJS revised the manuscript. All authors read and approved the final manuscript.

\section{Funding}

We acknowledge support by Open Access Publishing Fund of University of Tübingen.

\section{Availability of data and materials}

The datasets used and/or analysed during the current study are available from the corresponding author on reasonable request.

\section{Ethics approval and consent to participate}

The study was conducted in agreement with the ethical standards of the institutional and national research committee and with the 1964 Helsinki Declaration and its later amendments. This is an epidemiological study with anonymized, centrally collected, and online publicly available data. No patient consent or approval of the local ethics committee was required.

\section{Consent for publication}

Not applicable

\section{Competing interests}

The authors declare that they have no competing interests.

Received: 2 January 2020 Accepted: 4 February 2020

Published online: 21 February 2020

References

1. Bundesamt S. Bevölkerung Deutschlands bis 2060-12. koordinierte Bevölkerungsvorausberechnung. Wiesbaden: Statistisches Bundesamt; 2009.

2. Court-Brown $C M$, et al. The spectrum of fractures in the elderly. Bone Joint J. 2014:96-B(3):366-72.

3. Rapp K, et al. Epidemiology of hip fractures : systematic literature review of German data and an overview of the international literature. Z Gerontol Geriatr. 2019;52(1):10-6.

4. Bleibler $F$, et al. The health burden and costs of incident fractures attributable to osteoporosis from 2010 to 2050 in Germany--a demographic simulation model. Osteoporos Int. 2013;24(3):835-47.

5. Diaz AR, Navas PZ. Risk factors for trochanteric and femoral neck fracture. Rev Esp Cir Ortop Traumatol. 2018;62(2):134-41.

6. Kanis JA, et al. Risk of hip fracture according to the World Health Organization criteria for osteopenia and osteoporosis. Bone. 2000; 27(5):585-90.

7. Kannus $P$, et al. Stabilized incidence in proximal humeral fractures of elderly women: nationwide statistics from Finland in 1970-2015. J Gerontol A Biol Sci Med Sci. 2017;72(10):1390-3.

8. Clement ND, Court-Brown CM. Elderly pelvic fractures: the incidence is increasing and patient demographics can be used to predict the outcome. Eur J Orthop Surg Traumatol. 2014;24(8):1431-7.

9. Jerrhag $D$, et al. Epidemiology and time trends of distal forearm fractures in adults - a study of 11.2 million person-years in Sweden. BMC Musculoskelet Disord. 2017;18(1):240

10. Kannus $P$, et al. Declining incidence of fall-induced ankle fractures in elderly adults: Finnish statistics between 1970 and 2014. Arch Orthop Trauma Surg. 2016;136(9):1243-6.

11. Marks R. Hip fracture epidemiological trends, outcomes, and risk factors, 1970-2009. Int J Gen Med. 2010;3:1-17.

12. Icks A, et al. Trend of hip fracture incidence in Germany 1995-2004: a population-based study. Osteoporos Int. 2008;19(8):1139-45.

13. Kannus $P$, et al. Continuous decline in incidence of distal humeral fracture of older women in Finland. Aging Clin Exp Res. 2017;29(3):467-71.

14. Sumrein BO, et al. Proximal humeral fractures in Sweden-a registry-based study. Osteoporos Int. 2017;28(3):901-7.

15. Wildner M, Clark DE. Hip fracture incidence in east and West Germany: reassessement ten years after unification. Osteoporos Int. 2001;12(2):136-9.

16. Krankenhausstatistik - Diagnosedaten der Patienten und Patientinnen in Krankenhäusern, S.B., Zweigstelle Bonn, Diagnosedaten der Krankenhäuser ab 2000 (Fälle, Berechnungs- und Belegungstage, durchschnittliche Verweildauer). Gliederungsmerkmale: Jahre, Behandlungsort, Alter, Geschlecht, Verweildauer, ICD10-4-Steller In www.gbe-bund.de (Startseite > Krankheiten/Gesundheitsprobleme > Tabelle (gestaltbar): Diagnosedaten der Krankenhäuser nach Behandlungsort (ICD10-4-Steller, ab 2000)). 
17. Jo YH, Lee KH, Lee BG. Surgical trends in elderly patients with proximal humeral fractures in South Korea: a population-based study. BMC Musculoskelet Disord. 2019;20(1):136.

18. Hagino $\mathrm{H}$, et al. Changing incidence of hip, distal radius, and proximal humerus fractures in Tottori prefecture, Japan. Bone. 1999;24(3):265-70.

19. Singer $B R$, et al. Epidemiology of fractures in 15,000 adults: the influence of age and gender. J Bone Joint Surg (Br). 1998;80(2):243-8.

20. Court-Brown CM, Caesar B. Epidemiology of adult fractures: a review. Injury. 2006;37(8):691-7.

21. Palvanen $\mathrm{M}$, et al. Osteoporotic fractures of the distal humerus in elderly women. Ann Intern Med. 2003;139(3):W-W61.

22. Robinson $\mathrm{CM}$, et al. Adult distal humeral metaphyseal fractures: epidemiology and results of treatment. J Orthop Trauma. 2003;17(1):38-47.

23. Bergdahl C, et al. Epidemiology and patho-anatomical pattern of 2,011 humeral fractures: data from the Swedish Fracture Register. BMC Musculoskelet Disord. 2016;17:159.

24. Court-Brown $\mathrm{CM}$, et al. Fractures in older adults. A view of the future? Injury. 2018;49(12):2161-6.

25. Fortschreibung des Bevölkerungsstandes, S.B., Bevölkerungsanteile und gesamte Bevölkerung zum Stichtag 31.12. des jeweiligen Jahres. Gliederungsmerkmale: . In www.gbe-bund.de (Startseite > Rahmenbedingungen $>$ Bevölkerung $>$ Bevölkerungsstand $>$ Tabelle (gestaltbar): Bevölkerung am Jahresende, Bevölkerungsanteile).

26. Konig $\mathrm{M}$, et al. Historical trends in modifiable indicators of cardiovascular health and self-rated health among older adults: cohort differences over 20 years between the Berlin Aging Study (BASE) and the Berlin Aging Study II (BASE-II). PLoS One. 2018;13(1):e0191699.

27. Wilson S, Sharp CA, Davie MW. Health-related quality of life in patients with osteoporosis in the absence of vertebral fracture: a systematic review. Osteoporos Int. 2012;23(12):2749-68.

28. Gazibara T, et al. Falls, risk factors and fear of falling among persons older than 65 years of age. Psychogeriatrics. 2017;17(4):215-23.

29. Kim S, So WY. Prevalence and correlates of fear of falling in Korean community-dwelling elderly subjects. Exp Gerontol. 2013;48(11):1323-8.

30. Osteologie, D., DVO-Leitlinie 2017 zur Pro phylaxe, Diagnostik und Therapie der Osteoporose bei postmenopausalen Frauen und Männern. www. dvosteologie. org. Abgerufen am, 2018. 18 .

31. Bahrs C, et al. Trends in epidemiology and patho-anatomical pattern of proximal humeral fractures. Int Orthop. 2014;38(8):1697-704.

32. Merloz P. Optimization of perioperative management of proximal femoral fracture in the elderly. Orthop Traumatol Surg Res. 2017;104:S25-30.

\section{Publisher's Note}

Springer Nature remains neutral with regard to jurisdictional claims in published maps and institutional affiliations.

Ready to submit your research? Choose BMC and benefit from:

- fast, convenient online submission

- thorough peer review by experienced researchers in your field

- rapid publication on acceptance

- support for research data, including large and complex data types

- gold Open Access which fosters wider collaboration and increased citations

- maximum visibility for your research: over $100 \mathrm{M}$ website views per year

At $\mathrm{BMC}$, research is always in progress.

Learn more biomedcentral.com/submissions 